\title{
Geochemical assessment of the degree of isolation of edge-of-aquifer groundwater along a fringe of the southern High Plains Aquifer, USA
}

\author{
Gregg R. Davidson ${ }^{1} \cdot$ Robert M. Holt ${ }^{1}$ - Joan B. Blainey ${ }^{2}$
}

Received: 24 July 2018 / Accepted: 1 February 2019 / Published online: 26 February 2019

(C) The Author(s) 2019

\begin{abstract}
The edge of regional aquifers can be complex hydrodynamic systems with unique flow dynamics, water quality, and continuity relationships with the main aquifer system. A site near the southwestern margin of the High Plains Aquifer (USA) was investigated to characterize the local hydrogeology and its relationship with the regional aquifer system. Measurements of tritium, ion concentrations, oxygen and hydrogen isotopes, and hydraulic heads documented (1) a discontinuous saturated zone, (2) no inflow to the study area from the regional aquifer, (3) focused recharge beneath playas with limited local mixing between pockets of saturation, (4) outflow orthogonal to the regional aquifer flow direction, (5) localized multi-year reversals in flow direction following high precipitation events, and (6) a magnified influence of the paleo-erosional surface of the basement rock (Dockum Group) on groundwater isolation and flow direction. In isolated areas, groundwater can be trapped on decadal time scales by depressions in the Dockum, or by recharge events that periodically reverse groundwater gradients.
\end{abstract}

Keywords Hydrochemistry $\cdot$ Water isotopes $\cdot$ Groundwater isolation $\cdot$ Playas $\cdot$ USA

\section{Introduction}

Determining whether local groundwater is within the main body of a regional aquifer system, at the fringes with periodic connectivity, or isolated from the main aquifer system, can be important when identifying new construction sites with potential for contamination of the underlying groundwater. The motivation for the current study derived from the proposed placement of a low-level radioactive waste repository in West Texas, USA, near the border of New Mexico. The site, in Andrews County, lies near the southwestern edge of the High Plains Aquifer, a large regional aquifer system that extends beneath eight Midwestern states (Fig. 1). To ensure

Electronic supplementary material The online version of this article (https://doi.org/10.1007/s10040-019-01943-y) contains supplementary material, which is available to authorized users.

Gregg R. Davidson

davidson@olemiss.edu

1 Geology and Geological Engineering, University of Mississippi, University, MS 38677, USA

2 INTERA Inc., 9600 Great Hills Trail, Suite 300W, Austin, TX 78759, USA protection of the aquifer from possible leakage from the proposed facility, the Texas Department of Environmental Quality (TDEQ) required an aggressive assessment of the local groundwater system, including the degree to which it is connected with or isolated from the regional aquifer.

The High Plains Aquifer, often referred to as the Ogallala Aquifer, has been one of the most studied aquifer systems in the world because of its size, national importance in agricultural productivity, and the steady declines observed in the regional water table due to increasing withdrawals for irrigation (e.g. Stanton et al. 2011; Scanlon et al. 2012; BreñaNaranjo et al. 2014). The High Plains Aquifer is divided into three sub-aquifer systems, with geographic and potentiometric divides separating the larger system into the Northern, Central, and Southern High Plains groundwater systems (Fig. 1). The Southern High Plains (SHP) aquifer, lying beneath Texas and New Mexico, has experienced the most intensive groundwater depletion, with some locations experiencing water-level declines in excess of $50 \mathrm{~m}$ (Scanlon et al. 2012).

Groundwater flow is generally from the northwest to the southeast following the surface elevation (Guntentag et al. 1984). Average temperatures and precipitation vary significantly in the watershed. Higher average temperatures are observed moving south, and higher precipitation moving east. 

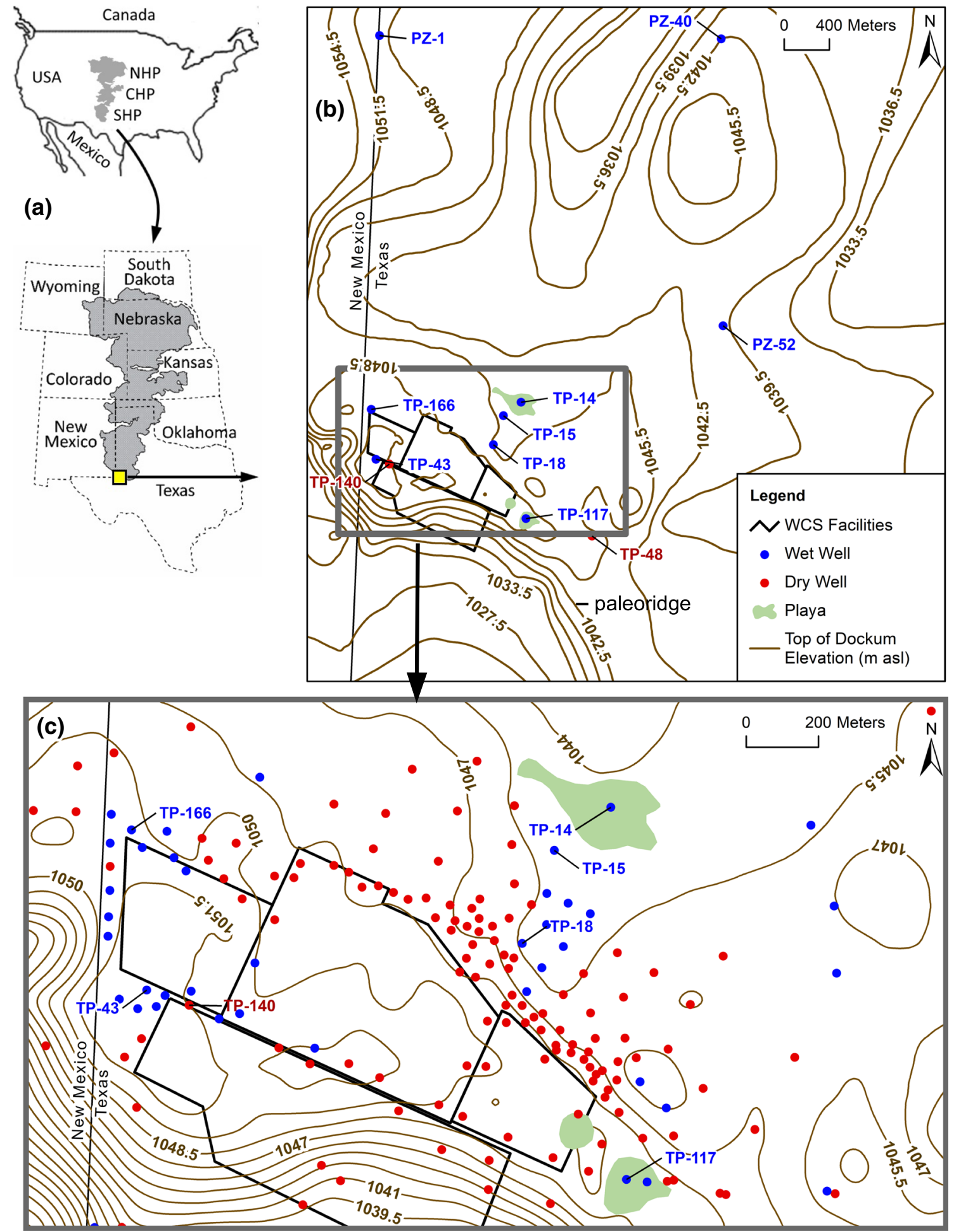

Fig. 1 a Location and delineation of the High Plains Aquifer (adapted from Qi 2010); NHP, CHP, SHP refers to Northern, Central, and Southern High Plains, respectively. b Site map with well locations. c Enlargement of site around the landfill. Contours are for the subsurface top of the
Dockum Group - elevation in $\mathrm{m}$ above sea level (m asl). The outline shows the footprint of the now operational Waste Control Specialists (WCS) facility

particularly in the SHP where over 20,000 playas have been identified (Fish et al. 1998; Quillin et al. 2005; Mulligan et al. 2014). Infrequent rainfall events fill these depressions, which 
serve as the primary source of recharge to the aquifer (Wood and Sanford 1995; Hovorka 1997; Scanlon and Goldsmith 1997; Fryar et al. 2001; Gurdak and Roe 2010).

The work of Wood and Sanford (1995) is particularly relevant to the current study. Wood and Sanford (1995) took advantage of an isotopic gradient in precipitation over the watershed to determine the primary source of recharge. Prevailing weather patterns tend to produce storms with lower $\delta^{18} \mathrm{O}$ and $\delta^{2} \mathrm{H}$ in precipitation moving upslope to the northwest (Nativ 1988; Nativ and Riggio 1990a, b). In general, groundwater tends to be depleted in the heavier isotopes relative to the annual weighted-mean composition of local precipitation due to mixing with groundwater flowing from higher in the watershed. At wells in or very near playas, however, groundwater is often more similar to local precipitation, consistent with focused recharge beneath the playas (Wood and Sanford 1995).

Nativ and Smith (1987) and Nativ (1988) provided an extensive overview of the hydrology and geochemistry of the SHP aquifer. Groundwater chemistry tends to be relatively constant where coarse-grained Ogallala Formation (upper Tertiary) and Quaternary deposits, up to $240 \mathrm{~m}$ in thickness, fill paleovalleys carved into the underlying pre-Miocene topography. Hydrochemistry is more varied where the aquifer thins and the percentage of coarse-grained sediments decreases. Hydrochemical facies (dominance based on eq/L) along the paleovalleys are mainly mixed-cation- $\mathrm{HCO}_{3}$ and $\mathrm{Ca}-\mathrm{HCO}_{3}$, with low tritium ( $\left.<2 \mathrm{TU}\right)$, and relatively low $\delta^{18} \mathrm{O}$ and $\delta^{2} \mathrm{H}$. Along paleodivides, hydrochemical facies include $\mathrm{Na}^{+}$or $\mathrm{Mg}^{+}$dominant cations, and $\mathrm{Cl}^{-}$or $\mathrm{SO}_{4}{ }^{2-}$ dominant anions, with higher tritium ( $>60 \mathrm{TU}$ in places in 1985; Nativ and Smith 1987), and higher $\delta^{18} \mathrm{O}$ and $\delta^{2} \mathrm{H}$ relative to the paleovalleys.

\section{Study site}

The study site in Andrews County, Texas, abuts the New Mexico border, $10 \mathrm{~km}$ east of Eunice, New Mexico (NM)Fig. 1 and see Figs. S1 and S2 of the electronic supplemental material (ESM). It lies on the border of the SHP aquifer boundary as reported by Guntentag et al. (1984) and updated USGS maps (Cederstrand and Becker 1999; Qi 2010). The site sits above a paleoridge in the Triassic Dockum Group, a series of low-permeability claystones and interbedded siltstones and sandstones, with approximately $50 \mathrm{~m}$ of erosional relief (Cronin 1969). Overlying unconsolidated sands and gravels of the Cretaceous Antlers Formation, late Tertiary Ogallala Formation, and partially age-equivalent Gatuna Formations vary in thickness from $\sim 4 \mathrm{~m}$ directly above the paleoridge to $\sim 34 \mathrm{~m}$ at the northern and southern edges of the study site. The Antlers Formation, highly silicified in places, may have acted as an erosion-resistant cap throughout late
Cenozoic time, maintaining the ridge as a drainage divide, while Ogallala and Gatuna Formation sediments were deposited on either side of the ridge. The Ogallala, Antlers, and Gatuna formations ( $O A G$ ) occupy the same hydrostratigraphic position of the HP aquifer. References to the SHP aquifer that follow are all within the OAG system. The Dockum paleoridge is roughly coincident with the surface topographic divide between the High Plains and Pecos Valley physiographic providences, and likely serves as a modern groundwater divide for the SHP aquifer. The primary interest of this study was groundwater encountered on the northern side of the paleoridge to determine the degree of connectivity with the regional High Plains aquifer system.

\section{Methods}

More than 250 wells and boreholes were placed at the site to map the geology and measure water levels, with a higher density near the location of the proposed landfill (Fig. 1). Wells for measuring shallow water levels penetrated the OAG, typically completed 0.2 to $1.6 \mathrm{~m}$ into the underlying Dockum Group (PZ-1 was completed $\sim 6 \mathrm{~m}$ into the Dockum). Water levels were recorded over time in all wells to document the thickness of the saturated zone (often zero), groundwater gradients, and changes in response to rainfall events. Several wells were placed within playas.

Geochemical and isotopic sampling was carried out in 11 wells during the summers of 2008 and 2011: two in playas (TP-14 and TP-117), two from areas with significant construction-related surface disturbance that resulted in ponding of precipitation (TP-43 and TP-166), and five from inter-playa sites. Of the latter, two wells were selected where water elevation readings suggested local connection with playa recharge (TP-15 and TP-18 with possible connection to TP-14) and three represent northern wells (PZ-1, PZ-40 and PZ-52) where groundwater models indicate localized (edge of aquifer) flow into the regional system (Blandford et al. 2003; Deeds and Jigmond 2015). Two wells were also sampled that contained only sump water below the top of the Dockum (TP48 and TP-140). These were included due to concerns by TDEQ that sump water might represent a thin or intermittent saturated zone in the OAG at these locations.

A minimum of three well volumes was purged (except for sump-only wells: TP-48, TP-140) at low flow rates using a bladder pump until $\mathrm{pH}$, oxidation reduction potential, conductivity, and dissolved oxygen stabilized. Sump-only wells were not purged because the emptied boreholes would not refill during or immediately after pumping. New sample tubing was used in each well, and the pump was cleaned and rinsed with deionized water between wells. Samples were collected in new high-density polyethylene bottles. Bottles for bulk chemistry were provided by the commercial laboratory, with 
separate pre-acidified (trace-metal grade $\mathrm{HNO}_{3}$ ) bottles for cations. Isotope samples were collected by filling each bottle from the bottom, allowing overflow to discharge initial water in contact with atmospheric air. Two wells had thicker saturated zones with the potential to sample at different depths. PZ-1, with $13 \mathrm{~m}$ of water above the Dockum, was only screened near the bottom, precluding sampling as a function of depth. PZ-40, with $4.4 \mathrm{~m}$ of water, was screened over the full saturated thickness. Sampling was carried out near the top and bottom of the profile with a low flow-rate purge and sampling, first at $1.5 \mathrm{~m}$ below the water table, then lowering the pump to the top of the Dockum and repeating the process. A consistent temperature difference of approximately $4{ }^{\circ} \mathrm{C}$ between the upper and lower depths (Table 1) indicated mixing inside the well was minimal during the purge and sampling.

All samples were passed through an inline $0.45-\mu \mathrm{m}$ cellulose acetate filter. Cations were measured by inductively coupled plasma mass spectrometry (ICPMS) and anions by ion chromatography (IC) by Hall Environmental Laboratory, Inc., in Albuquerque, NM for the 2008 samples, and TestAmerica Laboratories in Arvada, CO, for the 2011 samples. Alkalinity measurements were performed by titration onsite. Stable isotope analyses for oxygen and hydrogen

Table 1 Isotope and ion chemistry of site wells sampled in the summers of 2008 and 2011. Samples collected high and low in the water column of PZ-40 were nearly identical and average values are reported except for temperature. The lower elavation temperature was $20.7^{\circ} \mathrm{C}$ (reported in $\left(\delta^{18} \mathrm{O}\right.$ and $\left.\delta^{2} \mathrm{H}\right)$ were performed by the Center for Applied Isotope Studies at the University of Georgia in Athens, GA. Tritium analyses were performed by the University of Miami Tritium Laboratory in Miami, FL, after enrichment to achieve higher precision and lower detection limits. Stable isotope results are reported in per mil units (\%o) relative to the international standard Vienna Standard Mean Ocean Water (VSMOW). Tritium results are reported in tritium units, where $1 \mathrm{TU}$ represents one ${ }^{3} \mathrm{H}$ atom for every $10^{18}$ hydrogen atoms.

\section{Results and discussion}

\section{Hydrogeology}

A large number of dry wells is the most obvious testament to the spatially disconnected nature of the saturated zone at this location. Northeast of the Dockum paleoridge, 143 of 224 wells were dry (65\%) when measured in March 2011. Figure 1 (and larger map, Fig. S1 of the ESM) shows an increasing degree of aquifer fragmentation moving from northeast to southwest, consistent with the SHP aquifer thinning into discontinuous channels and isolated pockets at its edge (conceptual model in Fig. 2). Zones of saturation are

table), the upper elevation temperature was 25.1 (not reported). Ion concentrations are $\mathrm{mg} / \mathrm{L}$. Analytical precision $(1 \sigma)$ is equal to or less than: tritium, \pm 0.1 for values $<2 \mathrm{TU}, \pm 0.3$ for values $>2 \mathrm{TU} ; \delta^{18} \mathrm{O}, \pm 0.3 \% ; \delta^{2} \mathrm{H}$ $\pm 1.5 \%$ o. $\delta^{18} \mathrm{O}$ and $\delta^{2} \mathrm{H}$ values are relative to VSMOW

\begin{tabular}{|c|c|c|c|c|c|c|c|c|c|c|c|}
\hline \multirow{2}{*}{$\begin{array}{l}\text { Parameter } \\
\text { Well ID }\end{array}$} & \multicolumn{2}{|l|}{ Playa } & \multicolumn{2}{|c|}{ Inter-playa } & \multicolumn{3}{|c|}{ Northern inter-playa } & \multicolumn{2}{|c|}{ Surface disturbed } & \multicolumn{2}{|c|}{ Below top Dockum } \\
\hline & TP-117 & TP-14 & TP-15 & TP-18 & PZ-1 & PZ-40 & PZ-52 & $\mathrm{TP}-43$ & TP-166 & TP-140 & TP-48 \\
\hline Year sampled & 2011 & 2008 & 2011 & 2008 & 2011 & 2011 & 2008 & 2008 & 2011 & 2011 & 2011 \\
\hline Temp $\left({ }^{\circ} \mathrm{C}\right)$ & 17.5 & 22.7 & 23.7 & 26.0 & 21.0 & 20.7 & 26.0 & 20.8 & 20.8 & - & - \\
\hline $\mathrm{pH}$ & 7.2 & 7.0 & 7.4 & 7.7 & 7.4 & 7.1 & 7.4 & 7.1 & 7.2 & - & - \\
\hline $\mathrm{F}^{-}$ & 0.3 & 1.4 & 1.7 & 1.6 & 0.4 & 0.4 & 1.4 & 1.6 & 1.5 & 1.1 & 1.3 \\
\hline $\mathrm{Cl}^{-}$ & 200 & 12 & 18 & 7.8 & 57 & 150 & 78 & 210 & 450 & 120 & 22 \\
\hline $\mathrm{SO}_{4}^{2-}$ & 23 & 14 & 26 & 18 & 100 & 110 & 86 & 330 & 150 & 78 & 32 \\
\hline Alk. as $\mathrm{HCO}_{3}^{-\mathrm{a}}$ & 260 & 273 & 214 & 228 & 267 & 230 & 218 & 292 & 176 & 322 & 230 \\
\hline $\mathrm{Ca}^{2+}$ & 160 & 77 & 59 & 33 & 59 & 94 & 50 & 150 & 160 & 110 & 52 \\
\hline $\mathrm{Mg}^{2+}$ & 30 & 13 & 12 & 7.1 & 11 & 16 & 15 & 41 & 27 & 25 & 13 \\
\hline $\mathrm{Na}^{+}$ & 5.8 & 7.7 & 26 & 52 & 100 & 110 & 95 & 140 & 190 & 61 & 40 \\
\hline $\mathrm{K}^{+}$ & 8.5 & 7.7 & 5.1 & 4.0 & 3.4 & 4.6 & 4.2 & 3.6 & 7.8 & 3.8 & 3.9 \\
\hline TDS & 688 & 406 & 362 & 352 & 598 & 715 & 548 & 1,168 & 1,162 & 721 & 394 \\
\hline $\mathrm{Cl} / \mathrm{F}$ mole-ratio & 335 & 5 & 6 & 3 & 73 & 201 & 30 & 70 & 161 & 58 & 9 \\
\hline Charge bal. $(\%)^{\mathrm{b}}$ & -0.7 & -1.9 & -0.2 & -2.2 & 0.4 & 2.2 & -2.1 & -2.9 & -1.7 & -1.2 & 0.8 \\
\hline$\delta^{18} \mathrm{O}(\% \circ)$ & -5.6 & -5.9 & -6.1 & -5.6 & -6.6 & -5.9 & -5.9 & -5.8 & -6.2 & -6.0 & -6.3 \\
\hline$\delta^{2} \mathrm{H}(\% o)$ & -36 & -44 & -41 & -40 & -46 & -47 & -42 & -41 & -46 & -41 & -43 \\
\hline Tritium (TU) & 4.55 & 6.10 & 3.46 & 0.20 & -0.05 & 0.09 & 0.00 & 2.80 & 1.62 & 1.88 & 1.21 \\
\hline
\end{tabular}

${ }^{\text {a }}$ Alkalinity reported as bicarbonate

${ }^{\mathrm{b}}$ Charge balance: negative values indicate percent excess anions 


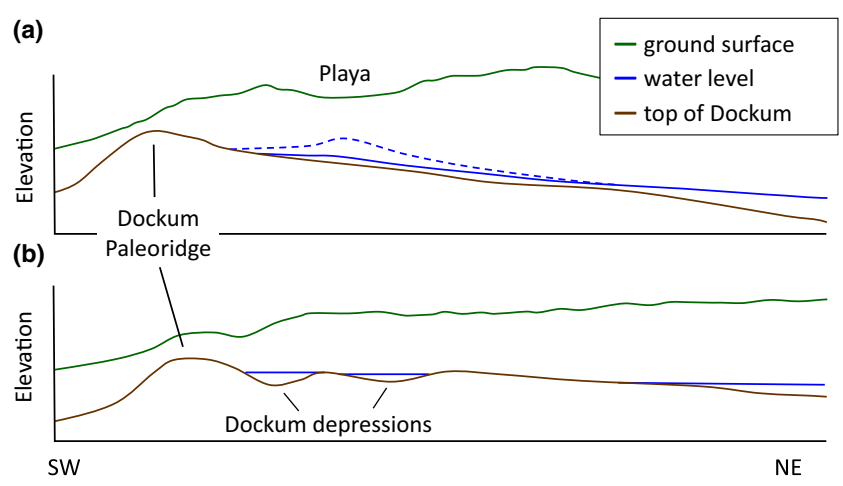

Fig. 2 Conceptual cross sections beginning west of the Dockum paleoridge, traveling northeast toward the SHP aquifer. Relative elevations are exaggerated for illustration purposes. a Continuous saturation along a paleovalley (e.g. TP-18/TP-15/TP-14 to west of PZ-40, Fig. 1). Dashed blue line represents water levels in 2006 following playa recharge event; solid blue line represents levels in 2012 (Fig. 3). b Discontinuous saturation in Dockum depressions (e.g. near TP-117 to PZ-52)

found in a paleochannel in the top of the Dockum running northeast from the paleoridge, and in depressions in the Dockum surface.

Changes in water levels following infrequent storm events were most pronounced at or near playas. Wells TP18, TP-15, and TP-14 lie along a paleochannel in the Dockum, suggesting a likely pathway of groundwater flow to the northeast. TP-14 was completed in the largest local playa in 2004, with initial water levels near $1,045.5 \mathrm{~m}$ above sea level (Fig. 3). A major storm event occurred in late 2004, but water levels were not measured again until late 2005 when TP-15 and TP-18 were completed. The first poststorm water-level in TP-14 was $1,047.3 \mathrm{~m}, 1.8 \mathrm{~m}$ higher than the previous year. TP-15 was at 1,046.9 $\mathrm{m}$ and TP-18 at $1,045.9 \mathrm{~m}$, exhibiting a groundwater gradient to the southwest, in the opposite direction of the paleochannel slope (Fig. 1; dashed line in Fig. 2a). Frequent water-level monitoring from 2005 to 2012 showed a steady decline in TP-14 and TP-15, with no apparent recharge from a series of smaller storms. TP-18 increased from the time of installation by approximately $0.2 \mathrm{~m}$ over the first 2 years, then declined steadily from 2008 to 2012 . Water levels in these three wells intersected (gradient of zero) in late 2010. Continued declines in water level resulted in a reversal in the hydraulic gradient to the northeast. These results suggest the formation of a groundwater mound beneath the playa in 2004, initially moving outward in all directions, but eventually draining northeast along the paleochannel.

TP-117 was completed in 2009 in a smaller playa overlying a nearby depression in the Dockum surface. Water levels steadily declined over the first 1.5 years of monitoring until July 2010, when monthly precipitation exceeded $10 \mathrm{~cm}$ (Fig. $3)$. Water levels rose abruptly by $0.8 \mathrm{~m}(1,048.9-1,049.7 \mathrm{~m})$, followed by a rapid decline, consistent with mounding and subsequent outflow beneath the playa.

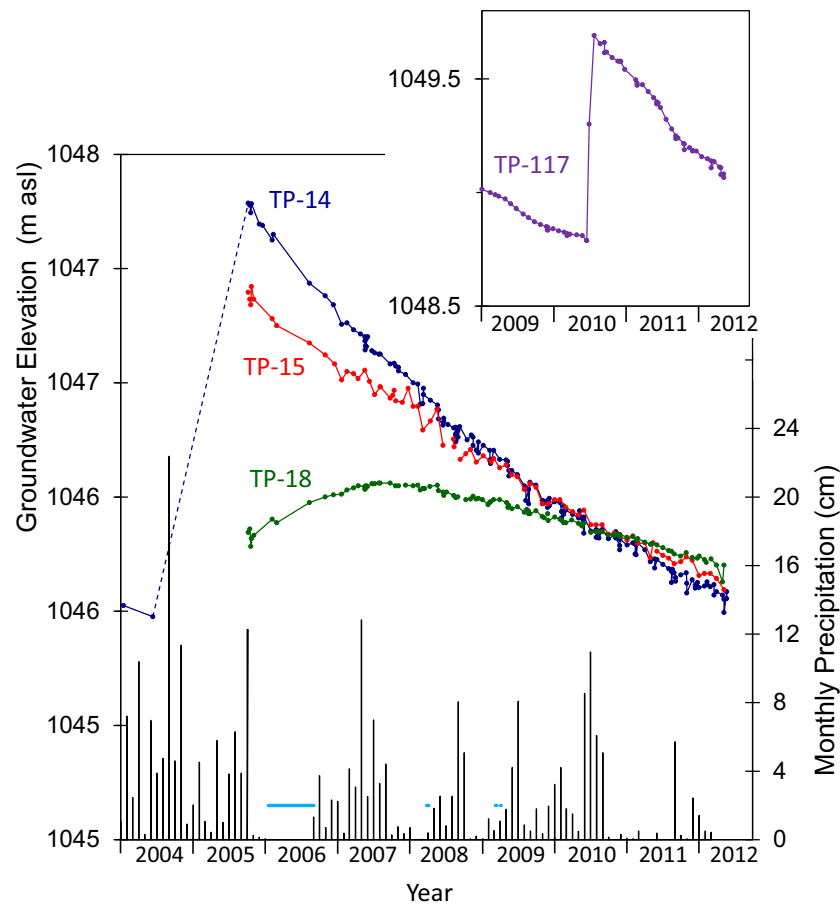

Fig. 3 Monthly precipitation and well water levels over time in TP-14, TP-15, TP-18 (in the same paleochannel of the Dockum Group) and TP117 (inset graph, aligned in time and proportional elevation scale). Horizontal blue bars represent periods of no precipitation data

Recharge events beneath the playas at TP-14 and TP-117 have the appearance of requiring independent minimum precipitation thresholds (Fig. 3). During the period of overlapping records, the substantial rise in water level in TP-117 in July 2010 was not replicated in TP-14. Storms predating installation of TP-117 did not produce a noticeable rise in water level in TP-14 except for the 1 month in which precipitation exceeded $20 \mathrm{~cm}$. The most probable explanation for a threshold is that low-precipitation events do not infiltrate deeply and soil water is removed by evapotranspiration. Recharge requires heavier precipitation, where ponded water infiltrates below the root zone. Differences in precipitation-thresholds between the two playas may be related to differences in surface runoff (requiring less precipitation to produce ponding at TP-117), differing hydraulic properties in the playa floors, or construction-related activities in the vicinity of TP-117 (a pit was under construction within $100 \mathrm{~m}$ of TP-117 at the time of the abrupt increase in water level).

The sump-only wells, TP-48 and TP-140, contained water above the bottom well screen which extended below the top of the Dockum. Water levels were always below the top of the Dockum, with fluctuations consistent with losses following sampling, and additions from condensate inside the well casing. Rivulets of condensate were visually observed when running a video camera down one well. These observations confirmed that the wells were effectively dry (no thin or intermittent saturated zone in the OAG layers), with sump-water contributed by borehole condensation. 


\section{Tritium}

The two highest tritium results were measured in the wells completed in playas: $6.10 \mathrm{TU}$ in TP-14 and $4.55 \mathrm{TU}$ in TP117 (Table 1). A sample collected 2 years earlier from TP-14 also measured 6.1 TU (B. Darling, LBG-Guyton Assoc., unpublished data, 2006). Though it is possible to get these concentrations from recharge during the era of surface testing of nuclear weapons (e.g. 75-TU water recharged 45 years ago), it is much more plausible that they represent modern precipitation in both wells, with variation reflecting either differences in the tritium content of specific storms, or variable mixing with water from earlier recharge events. Prior to nuclear testing, tritium levels in precipitation for the region were reported to be near 6 TU (Thatcher 1962). More recent measurements in Albuquerque, NM (reported approximately monthly from 2000 to 2005) ranged from 4.8 to $9.8 \mathrm{TU}$, with a mean of 7.4 \pm 1.4 TU (IAEA 2015).

Tritium levels in TP-15 and TP-18 (within the paleochannel) were 3.46 and $0.20 \mathrm{TU}$, respectively. A value of $\sim 3.5 \mathrm{TU}$ can be indicative of water recharged $10-15$ years prior to sampling, or of mixing of recently recharged water with older water. Based on the hydraulic gradient and knowledge of the precipitation event in 2004, both explanations are probable. Recharging water will force older water to flow outward, with dispersion acting to partially mix new and old water. A tritium level of $0.20 \mathrm{TU}$ in TP-18 represents a mean residence time of 60 years, assuming an initial value of $6 \mathrm{TU}$ and little mixing. This suggests that significant recharge events in this region are relatively rare.

The declining tritium content moving southwest from TP-14 to TP-18 is consistent with observations from the hydraulic gradient over time. Recharged water initially mounds beneath the playa at TP-14 with flow outward in all directions. This includes temporary (though multi-year) flow up the paleochannel to the southwest, in the opposite direction of the general flow system. If recharge events occur in playas on a decadal time scale, groundwater in the area of TP-18 may be partially trapped, moving up and down the upper reach of the paleochannel as a recharge mound repeatedly forms and dissipates.

Tritium levels in TP-117 also indicate recent recharge, though less can be said about the fate of water at this location without tritium data from nearby wells. Proximity to a depression in the Dockum surface suggests filling from playa recharge with periodic overflow.

The two wells completed in areas with significant surface disturbance, leading to occasional ponding of water, also contained measurable tritium. TP-166 and TP-43 contained 1.62 and $2.80 \mathrm{TU}$, respectively, consistent with lesser recharge and mixing with older water following ponding. Examination of historical aerial photographs identified two small playas near TP-43 and an area of enhanced vegetation north of TP-166 where natural recharge may have also occurred.

Tritium levels in the three northern wells-PZ-1, PZ-40, and PZ-52 - were at or near zero. Whether at or slightly above zero, tritium levels at all three wells indicate water that was recharged and isolated from the atmosphere prior to 1950. A sample collected near the bottom of PZ-40 measured $0.13 \pm$ $0.09 \mathrm{TU}$; a sample near the top measured $0.04 \pm 0.09 \mathrm{TU}$. The high and low sampling was performed to differentiate aerial recharge versus focused recharge beneath the playas (Wood and Sanford 1995; Scanlon and Goldsmith 1997), with the expectation that aerially distributed recharge would produce a vertical gradient in tritium in the saturated zone. The absence of a vertical gradient (within analytical uncertainty), and near zero tritium near the top of the aquifer, is more consistent with recharge beneath the playas followed by lateral flow.

The two wells containing sump water below the Dockum surface, TP-48 and TP-140, were not purged. Tritium concentrations between 1 and $2 \mathrm{TU}$ may result from a combination of condensation of water vapor and subsequent interaction with atmospheric air.

\section{Water chemistry}

The major ion composition of regional and site wells is illustrated in the Piper diagram in Fig. 4. Records from the Texas Water Development Board include 22 wells with water quality data within a $25-\mathrm{km}$ radius north, northeast, and east of the site (Table S1 of the ESM). Reporting dates for each well range from 1963 to 2016. On a mole-percent basis, $\mathrm{Na}^{+}$is the dominant cation for all but three wells, and $\mathrm{Cl}^{-}$or $\mathrm{HCO}_{3}{ }^{-}$is the dominant anion. All cluster relatively closely in Fig. 4. Total dissolved solids (TDS), calculated from reported ion concentrations, ranged from 445 to $1,725 \mathrm{mg} / \mathrm{L} ; \mathrm{Cl} / \mathrm{F}$ mole-ratios ranged from 6 to 241. Cl/F ratios are reported for this study for two reasons: (1) $\mathrm{Cl}^{-}$and $\mathrm{F}^{-}$tend to be conservative tracers, varying in proportion only if there is more than one source (e.g. variable mineralogy at recharge point), and (2) the ratios showed significant variation between sample groups at this site.

Water chemistry from the study site varied considerably relative to the wells in the local SHP aquifer, and exhibited greater internal variability (Table 1 and Table $\mathrm{S} 1$ of the ESM). The greatest differences from regional wells is observed in playa wells (TP-14 and TP-117; Fig. 4). TP-15 and TP-18, linked hydraulically with the playa at TP-14, have similar TDS concentrations and plot along a common trend line on Fig. 4, shifting from $\mathrm{Ca}^{2+}$ to $\mathrm{Na}^{+}$as the dominant cation moving along the pre-2010 hydraulic gradient from TP-14 to TP15 to TP-18. $\mathrm{HCO}_{3}{ }^{-}$is the dominant anion for all three wells. $\mathrm{Cl} / \mathrm{F}$ mole-ratios are nearly the same in these wells, varying over a small range from 3 to 6 . 


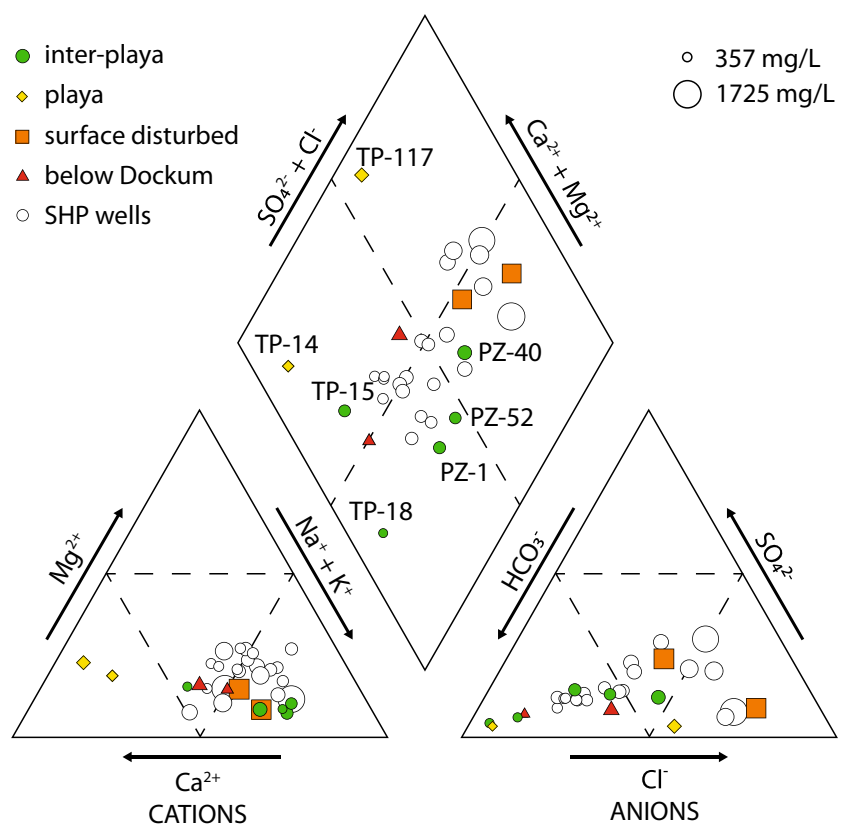

Fig. 4 Piper plot of major ion chemistry (mole percent). Select wells are labeled. The size of the data markers are proportional to the TDS (minimum and maximum values shown in legend). SHP wells are from wells within a $25-\mathrm{km}$ radius north, northeast, and east of the study site (data in Table S1 and locations shown in Fig. S2 of the ESM)

TP-117 is in a playa, similar to TP-14, but with unique chemistry relative to TP-14, TP-15, or TP-18 (wells in a common paleochannel). Wells between TP-117 and TP-14/-15/-18 were dry. Though the dominant cation in TP-117 is $\mathrm{Na}^{+}$, similar to TP14 , the dominant anion is $\mathrm{Cl}^{-}$, and the TDS concentration is 70 $95 \%$ higher than the other three wells. The $\mathrm{Cl} / \mathrm{F}$ mole-ratio is 335 , two orders-of-magnitude higher than the other nearby wells. These differences are consistent with the presence of discrete, discontinuous pockets of groundwater, with geochemistry reflecting heterogeneity in the subsurface mineralogy.

The three wells thought to be on the edge of the contiguous SHP aquifer-PZ-1, PZ-40, and PZ-52 - more closely resemble the regional wells, though plotting at the outside edge of the regional-well cluster in Fig. 4. The PZ wells fall within the range of $\mathrm{TDS}$ and $\mathrm{Cl} / \mathrm{F}$ ratios of the regional wells. Interestingly, the playa wells are significantly lower in $\mathrm{Na}^{+}$ (mole-percent) than the regional wells, while the $\mathrm{PZ}$ wells are among the highest in percent $\mathrm{Na}^{+}$(playa and $\mathrm{PZ}$ wells fall on opposite sides of the regional-well cluster in Fig. 4). Localized flow from the paleoridge to the PZ wells appears to encounter minerals richer in $\mathrm{Na}$, on average, than in the SHP aquifer to the northeast. These results further indicate that the study site occupies a hydraulic high point at the aquifer fringe. The regional SHP aquifer does not flow into and out of the study site, but receives intermittent contributions derived primarily from recharge events at playas northeast of the paleoridge.

The two wells placed at locations with significant surface disturbance and artificial ponding of rainwater group within the regional wells on Fig. 4, with TDS values much higher than the other site wells, which is consistent with the current understanding of recharge processes in the High Plains aquifer. Accumulated salts in the unsaturated zone are common except at playas where recharging water periodically flushes the unsaturated zone (Wood and Sanford 1995; Scanlon and Goldsmith 1997). At TP-43 and TP-166, precipitation did not historically pond. The higher TDS values are consistent with recent flushing of salts from the unsaturated zone due to recharge through sediments that were not historically a conduit for recharge.

Overall results are consistent with the observations of Nativ and Smith (1987) and Nativ (1988), with lower variability in water chemistry where the aquifer has a greater vertical thickness, and higher variability where the aquifer thins at the edges or over paleoridges. Dissimilarity in TDS, anion ratios, and major ion concentrations of groundwater at the study site indicate interaction with a heterogeneous distribution of minerals and precipitated salts at points of recharge and in the subsurface, and differences in residence time. The playa at TP-117 sits over a nearby depression in the top of the Dockum that will retain groundwater longer, which may account for the higher TDS relative to TP-14 where the playa sits over a paleochannel in the Dockum (Fig. 2).

The ion chemistry of the sump-only wells, TP-48 and TP140 , plot at the low- $\mathrm{Na}^{+}$edge of the regional-well cluster in Fig. 4 . The chemistry data do not supply any unique information regarding the source of the sump water, because it could derive from either an intermittent saturated zone or simply from interaction of condensate water with local minerals outside and inside the casing.

\section{Stable isotopes}

In the SHP aquifer, an isotopic gradient exists with lower $\delta^{18} \mathrm{O}$ and $\delta^{2} \mathrm{H}$ values up-gradient to the northwest that has been attributed to increased fractionation of precipitation as storms travel inland to higher elevations (Nativ 1988; Nativ and Riggio 1990a, b; Fig. 5a). Isotopic composition of precipitation also varies with season, though temporal variation is minimized in groundwater as recharge mixes in the subsurface. Spatial differences in the $\delta^{18} \mathrm{O}$ and $\delta^{2} \mathrm{H}$ of precipitation (weighted annual mean) have the larger influence on groundwater composition (Wood and Sanford 1995).

In the regional system, groundwater associated with playas tends to have higher $\delta^{18} \mathrm{O}$ and $\delta^{2} \mathrm{H}$ values relative to groundwater from nonplaya wells (Fig. 5b). The differences in isotopic signatures indicate that groundwater between playas is a mix of local precipitation and isotopically lighter water recharged higher in the watershed, while water beneath or near playas is of mostly local origin that has not yet mixed with regional flow (Wood and Sanford 1995).

In contrast to regional observations, shallow groundwater at the study site exhibits no separation of playa and inter-playa wells 


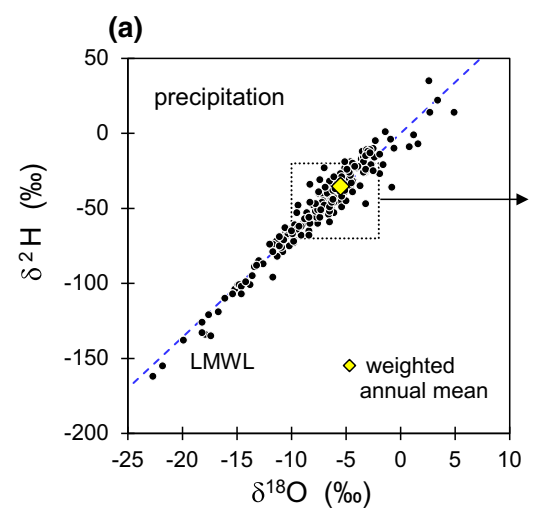

(b)

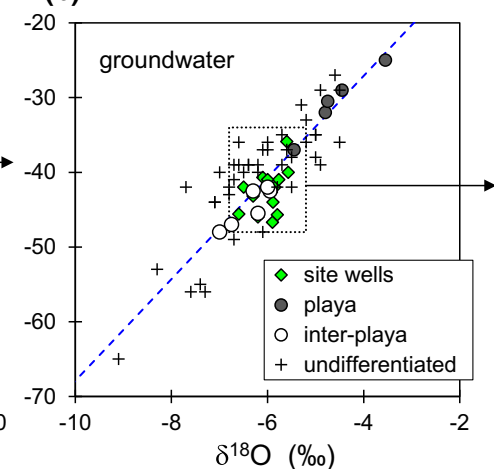

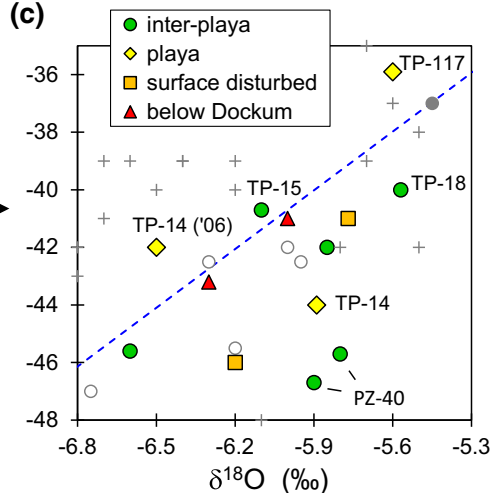

Fig. $5 \delta^{18} \mathrm{O}$ vs $\delta^{2} \mathrm{H}$. Dashed boxes indicate data range represented in each subsequent graph. a Precipitation from Nativ (1988) and Nativ and Riggio (1990a, b). Data represents every rainfall event $(n=216)$ over a 1 -year period at five locations (Amarillo, Lubbock, Midland, Clovis, and Paducah). Best-fit line represents the local meteoric water line (LMWL). b Playa and inter-playa groundwater from Wood and Sanford (1995);

(Fig. 5c; Table 1). The lack of any separation or grouping of the isotopic data between the different designations (playa, interplaya, surface disturbed) is consistent with a local groundwater system that does not receive water from the regional aquifer. In the absence of flow of regional groundwater through this area, there is no isotopically light groundwater (recharged higher in the regional system) available to mix with heavier water locally recharged beneath the playas. As a result, the range in isotopic values is small, and there is no clear distinction between groundwater collected from within and between playas or from disturbed sites. All sampled water appears to be of local origin.

\section{Conclusions}

Results from this study draw attention to the unique character of groundwater flow and geochemical history that can exist at the fringes of a regional aquifer system. In the Southern High Plains aquifer, predominant flow is to the southeast along an elevation gradient. Water chemistry is generally dominant in $\mathrm{Na}^{+}$and either $\mathrm{Cl}^{-}$or $\mathrm{HCO}_{3}{ }^{-}$(mole-percent). An isotopic gradient $\left(\delta^{2} \mathrm{H}, \delta^{18} \mathrm{O}\right)$ in precipitation over the watershed, coupled with focused recharge at playas, results in a disparity between the isotopic composition of groundwater at playa wells (dominated by local recharge) and inter-playa wells (local recharge mixed with water recharged higher in the watershed).

Groundwater at the study site is represented by a fragmented saturated zone with an increasing number of dry wells moving southwest over a paleoridge in the underlying Dockum Group. Recharge into isolated pockets of groundwater occurs at playas, with eventual outflow to the northeast, orthogonal to the regional aquifer flow direction. The site does not receive groundwater inflow from higher in watershed, as evidenced by the absence of significant differences in $\delta^{2} \mathrm{H}$ and $\delta^{18} \mathrm{O}$ for playa and inter- undifferentiated groundwater from Nativ and Smith (1987); and site groundwater from this study. c Enlargement with site well-types differentiated; select wells labeled (marker shapes and colors correspond with those in Fig. 4). TP-14 ('06) is from B. Darling, LBG-Guyton Assoc., unpublished data, 2006. Two values for PZ-40 represent samples collected near the top and bottom of the well

playa groundwater, and by large differences in ion chemistry between pockets of saturation. The variability in water chemistry (ion dominance and TDS) is also larger between site wells than between wells within the regional SHP aquifer.

Tritium results were consistent with focused recharge at playas, with outflow controlled in large part by the paleotopography of the Dockum. In isolated places, groundwater may be trapped on decadal time scales in depressions in the Dockum, or in paleochannels upslope from a playa where recharge events can produce multi-year reversals in the local hydraulic gradient. The uniqueness of the hydrologic system at this site emphasizes the need for thorough site investigation when selecting or licensing environmentally sensitive construction projects near the edge of an aquifer system.

Acknowledgements Appreciation is expressed for insightful comments by anonymous reviewers.

Funding information This work was carried out under contract with Waste Control Specialists, LLC, under the oversight of the Texas Department of Environmental Quality.

Open Access This article is distributed under the terms of the Creative Commons Attribution 4.0 International License (http:// creativecommons.org/licenses/by/4.0/), which permits unrestricted use, distribution, and reproduction in any medium, provided you give appropriate credit to the original author(s) and the source, provide a link to the Creative Commons license, and indicate if changes were made.

\section{References}

Blandford TN, Blazer DJ, Calhoun KC, Dutton AR, Naing T, Reedy RC, Scanlon BR (2003) Groundwater availability of the southern Ogallala Aquifer in Texas and New Mexico numerical simulations through 2050, Texas Water Dev. Board Draft Rep., 160 pp. http:// www.twdb.texas.gov/groundwater/models/gam/ogll_s/OGLL_S Full_Report.pdf?d=4803.899999940768. Accessed June 2018 
Breña-Naranjo JA, Kendall AD, Hyndman DW (2014) Improved methods for satellite-based groundwater storage estimates: a decade of monitoring the High Plains Aquifer from space and ground observations. Geophys Res Lett 41:6167-6173. https://doi.org/10. 1002/2014GL061213

Cederstrand JR, Becker MF (1999) Digital map of areas of little or no saturated thickness for the High Plains Aquifer in parts of Colorado, Kansas, Nebraska, New Mexico, Oklahoma, South Dakota, Texas, and Wyoming. US Geol Surv Open-File Rep 99-266. https://doi.org/ $10.3133 /$ ofr 99266

Cronin JG (1969) Groundwater in the Ogallala Formation in the Southern High Plains of Texas and New Mexico. US Geol Surv Hydrol Invest HA-330, 9 pp

Deeds NE, Jigmond M (2015) Numerical model report for the High Plains aquifer system groundwater availability model. Texas Water Dev. Board Draft Rep., 640 pp. http://www.twdb.texas.gov/ groundwater/models/gam/hpas/HPAS_GAM_Numerical_Report. pdf. Accessed June 2018

Fish EB, Atkinson EL, Shanks CH, Brenton CM, Mollhagen T (1998) Playa lakes digital database. College Agric. Nat. Res. Tech. Pub. Y-9-813, Texas Tech University, Lubbock, TX, 37 pp

Fryar AE, Mullican WF III, Macko SA (2001) Groundwater recharge and chemical evolution in the southern High Plains of Texas, USA. Hydrogeol J 9:522-542. https://doi.org/10.1007/s10040-001-161-9

Guntentag ED, Heimes FJ, Krothe NC, Luckey RR, Weeks JB (1984) Geohydrology of the High Plains Aquifer in Parts of Colorado, Kansas, Nebraska, New Mexico, Oklahoma, South Dakota, Texas, and Wyoming. US Geol Surv Prof Pap 1400-B, 72 pp

Gurdak JJ, Roe CD (2010) Review: recharge rates and chemistry beneath playas of the High Plains aquifer, USA. Hydrogeol J 18:1747-1772. https://doi.org/10.1007/s10040-010-0672-3

Hovorka SD (1997) Quaternary evolution of ephemeral playa lakes on the southern High Plains of Texas, USA: cyclic variations in lake level recorded in sediments. J Paleolimnol 17:131-146. https://doi. org/10.1023/A:1007998902734

IAEA (2015) Global networks of isotopes in precipitation and rivers (GNIP, GNIR). https://nucleus.iaea.org/Pages/GNIPR.aspx. Accessed June 2018

Mulligan KR, Barbato LS, Seshadri S (2014) Playas and wetlands database. Center for Geospatial Technology, Texas Tech University. http://www.depts.ttu.edu/geospatial/center/pwd/PlayasDocument. pdf. Accessed June 2018

Nativ R (1988) Hydrogeology and hydrochemistry of the Ogallala Aquifer, Southern High Plains, Texas Panhandle and Eastern New
Mexico. Univ. Texas Bur. Econ. Geol., Rep. Invest no. 177, University of Texas, Austin, TX, $64 \mathrm{pp}$

Nativ R, Riggio R (1990a) Precipitation in the Southern High Plains: meteorologic and isotopic features. J Geophys Res 95(D13):22, 559-22,564. https://doi.org/10.1029/JD095iD13p22559

Nativ R, Riggio R (1990b) Meteorologic and isotopic characteristics of precipitation events with implications for ground-water recharge, Southern High Plains. In: Gustavson TC (ed) Geologic framework and regional hydrology: Upper Cenozoic Blackwater Draw and Ogallala Formations, Great Plains. Symposium SP6, Bur. Econ. Geol., Univ. Texas Austin, Austin, TX, pp 152-179

Nativ R, Smith DA (1987) Hydrogeology and geochemistry of the Ogallala aquifer, southern High Plains. J Hydrol 91:217-253. https://doi.org/10.1016/0022-1694(87)90206-X

Qi SL (2010) Digital map of the aquifer boundary of the High Plains aquifer in parts of Colorado, Kansas, Nebraska, New Mexico, Oklahoma, South Dakota, Texas, and Wyoming. US Geol Surv Data Series 543. https://doi.org/10.3133/ds543

Quillin JP, Zartman RE, Fish EB (2005) Spatial distribution of playa basins on the Texas High Plains. Tex J Agric Nat Resour 18:1-14

Scanlon BR, Goldsmith RS (1997) Field study of spatial variability in unsaturated flow beneath and adjacent to playas. Water Resour Res 33:2239-2252. https://doi.org/10.1029/97WR01332

Scanlon BR, Faunt CC, Longuevergne L, Reedy RC, Alley WM, McGuire VL, McMahon PB (2012) Groundwater depletion and sustainability of irrigation in the US High Plains and Central Valley. PNAS 109:9320-9325. https://doi.org/10.1073/pnas. 1200311109

Stanton JS, Qi SL, Ryter DW, Falk SE, Houston NA, Peterson SM, Westenbroek SM, Christenson SC (2011) Selected approaches to estimate water-budget components of the High Plains, 1940 through 1949 and 2000 through 2009. US Geol Surv Sci Invest Rep 2011$5183,79 \mathrm{pp}$

Thatcher LL (1962) The distribution of tritium fallout in precipitation over North America. Bull Int Assoc Sci Hydrol 7:48-58. https:// doi.org/10.1080/02626666209493255

Wood WW, Sanford WE (1995) Chemical and isotopic methods for quantifying ground-water recharge in a regional, semiarid environment. Ground Water 33:458-468. https://doi.org/10.1111/j.17456584.1995.tb00302.x 